Doc. dr. sc. Ivana Dropulić Izv. prof. dr. sc. Maja Letica ${ }^{2}$

\title{
UTJECAJ INTEGRIRANOG INFORMACIJSKOG SUSTAVA NA AKTIVNOSTI UPRAVLJAČKOG RAČUNOVODSTVA U DJELATNOSTI OSIGURANJA BOSNE I HERCEGOVINE
}

\begin{abstract}
THE IMPACT OF INTEGRATED INFORMATION SYSTEM ON MANAGEMENT ACCOUNTING ACTIVITIES: CASE OF THE INSURANCE SECTOR IN THE BOSNIA AND HERZEGOVINA
\end{abstract}

SAŽETAK: Svrha ovoga istraživanja je analiza utjecaja implementacije integriranog informacijskog sustava (IIS) na praksu upravljačkog računovodstva zbog postojanja ambivalentnih rezultata u postojećoj literaturi navedenog odnosa. Istraživanje je provedeno u djelatnosti osiguranja Bosne i Hercegovine tijekom 2020. godine u kojem je sudjelovalo $6(22,22 \%)$ društava za osiguranje i reosiguranje, koja zajednički drže $49,44 \%$ tržišnog udjela, kako bi se utvrdio utjecaj implementacije IIS na praksu upravljačkog računovodstva te na sposobnost društva da adekvatno odgovori na aktualnu COVID-19 krizu. IIS, u djelatnosti osiguranja BIH, se upotrebljava u prosjeku već 9 godina te se, između ostaloga, može uočiti i visok stupanj iskorištenosti njegovih mogućnosti (85 \%) te uspješna implementacija. Implementirani IIS je značajno doprinio efikasnom odgovoru na COVID-19 krizu u smislu prilagodbe na novonastalu situaciju, smanjenju gubitaka i reorganiziranju načina rada uslijed COVID-19 krize. Prema dobivenim rezultatima, može se zaključiti kako IIS značajno utječe na interno izvještavanje menadžera te na implementaciju modernih tehnika upravljačkog računovodstva.

KLJUČNE RIJEČI: integrirani informacijski sustav (IIS), upravljačko računovodstvo, djelatnost osiguranja, Bosna i Hercegovina

JEL: M15, M41, M49

Doc. dr. sc. Ivana Dropulić, Ekonomski fakultet, Sveučilište u Splitu, Cvite Fiskovića 5, 21000 Split, ivana.dropulic@efst.hr

2 Izv. prof. dr. sc. Maja Letica, Ekonomski fakultet, Sveučilište u Mostaru, Matice hrvatske bb, 88000 Mostar,maja.letica@ef.sum.ba 


\begin{abstract}
The purpose of this research is to analyze the effect of integrated information system (IIS) on management accounting practice due to the existence of ambivalent results in the literature of this relationship. The survey was conducted in the insurance sector of the Bosnia and Herzegovina during 2020, in which six (22.22\%) insurance and reinsurance companies participated, which hold $49.44 \%$ market share, in order to determine the effect of IIS implementation on the management accounting practice and the company's ability to adequately respond to the current COVID-19 crisis. IIS, in the insurance sector of BIH, have been used for an average of 9 years and a high degree of utilization of its capabilities (85\%) and successful implementation can be noticed. The implemented IIS has significantly contributed to the effective response to the COVID-19 crisis in terms of adapting to the new situation, reducing losses and reorganizing the way of working. According to the obtained results, IIS significantly affects the internal reporting of managers and the implementation of modern management accounting techniques.
\end{abstract}

KEYWORDS: integrated information system (IIS), management accounting, insurance sector, Bosnia and Herzegovina

JEL: M15, M41, M49

\title{
1. UVOD
}

S obzirom na činjenicu da društva danas posluju u izrazito konkurentskom, neizvjesnom, rapidno modificirajućem i globaliziranom poslovnom okruženju upotreba informacijskih tehnologija, kao što su integrirani informacijski sustavi (IIS), je postala neophodna kako bi se zadovoljile rastuće potrebe društva za informacijama potrebnih za donošenje pravovremenih poslovnih odluka, te posljedično povećanja konkurentnosti. IIS je integrirani informacijski sustav koji obuhvaća sve integrirane sustave u društvu odnosno, ERP sustave (engl. Enterprise Resource Planning - sustav planiranja resursa poduzeća) i specijalizirane aplikacije. ERP je integrirani informacijski sustav dizajniran za koordiniranje i upravljanje svim resursima, informacijama i aktivnostima potrebnima za izvođenje poslovnih procesa dok specijalizirane aplikacije predstavljaju samostalne aplikacije (izvan ERP-a), povezane $\mathrm{s}$ jedinstvenom bazom podataka, koje podupiru pojedine procese/aktivnosti (npr. konsolidacija, budžetiranje, odnosi s kupcima i sl.). Implementacija IIS utječe na cjelokupno poslovanje društva pa tako i na praksu i zaposlenike upravljačkog računovodstva. U ovome istraživanju razmatra se utjecaj implementacije IIS na različite dimenzije upravljačkog računovodstva i to na: 1) prikupljanje podataka, 2) interno izvještavanje menadžera, 3) izradu i kontrolu financijskog plana, 4) implementaciju modernih tehnika upravljačkog računovodstva te na 5) zaposlenike koji sudjeluju u internom izvještavanju. Osim navedenog, istražit ce se i utjecaj implementacije IIS na sposobnost društva da adekvatno odgovori na aktualnu COVID-19 krizu.

Primarni poriv za ovo istraživanje jest činjenica da su učinci implementacije IIS na praksu upravljačkog računovodstva još uvijek neprecizni i neujednačeni. Budući da je i u sektoru osiguranja prisutna primjena informacijskih tehnologija pa tako i IIS, koja sve više utječe i mijenja način poslovanja cilj ovoga rada je istražiti kako je implementacija IIS utjecala na praksu upravljačkog računovodstva u sektoru osiguranja Bosne i Hercegovine. Rad se sastoji od pet poglavlja uključujući uvod i zaključak. U uvodnom dijelu se objašnja- 
va uloga i značaj IIS odnosno njegov utjecaj na praksu upravljačkog računovodstva. Drugi dio pruža prikaz prethodnih istraživanja integriranog informacijskog sustava i njegovog utjecaja na različite dimenzije upravljačkog računovodstva. Treći dio prikazuje uzorak i metodologiju istraživanja dok su rezultati istraživanja prikazani u četvrtom dijelu. Na kraju rada, u petom dijelu, iznose se osnovni zaključci do kojih se došlo provedbom istraživanja te preporuke za daljnja istraživanja.

\section{PRIKAZ PRETHODNIH ISTRAŽIVANJA}

Za dugoročno uspješno poslovanje društvu je neophodna potpora integriranog informacijskog sustava (IIS), kao što je sustav planiranja resursa poduzeća (ERP), koji su postali neophodan instrument u upravljačkom računovodstvu, ali i jedan od glavnih pokretača promjena u području upravljačkog računovodstva (Dropulić, 2019, 63). ERP je programsko rješenje koje obuhvaća cjelokupno poslovanje društva, podržava i integrira rad svih službi i odjela te povezuje sve unutarnje i vanjske poslovne procese društva (Milanović Glavan, 2014, 40). Unatoč postojanju značajnog broja istraživanja odnosa između implementacije IIS i prakse upravljačkog računovodstva rezultati u postojećoj literaturi navedenog odnosa su nejasni i nekoncizni zbog čega postoji ograničeno razumijevanje navedenog odnosa, kako teorijski tako i u praksi (Dropulić, 2019, 63).

Implementacijom IIS postiže se integracija podataka budući da se svi podaci koji se prikupljaju unutar, ali i van društva, pohranjuju u jedinstvenu bazu podataka koja omogućava korisnicima izravan pristup bilo kojem podatku u bilo kojem trenutku. S obzirom na navedeno, prethodna su istraživanja potvrdila da se nakon implementacije IIS podaci prikupljaju i obrađuju jednostavnije i brže (Colmenares, 2009, 5; Kanellou i Spathis, 2011, 368; Etemadi i Kazeminia, 2014, 512; Pervan i Dropulić, 2019, 34). Prema tome, IIS pospješuje donošenje poslovnih odluka pružanjem opsežnih, točnih i pravovremenih informacija za cjelokupno društvo. Društva s implementiranim IIS imaju veći djelokrug informacija te brže obrađuju podatke potrebne za donošenje poslovnih odluka te ostvaruju i veću dodanu vrijednost u vidu povratnih informacija za poboljšanje performansi poslovanja u budućnosti (Dwi May Adi Indra, Noorlailie i Isnalita, 2018, 86).

Također, očekuje se i da će implementacija IIS utjecati na interno izvještavanje menadžera odnosno na povećanje učestalosti i broja različitih vrsta periodičnih izvještaja dok istovremeno dolazi do smanjenja potrebnog vremena za samo interno izvještavanje. Razlog povećanja mogućnosti izvještavanja je IIS kojim se povećava kapacitet za prikupljanje, analiziranje i pohranu podataka (Granlund i Malmi, 2002, 315). Dakle, upravljačke računovođe imaju mogućnost brzog provođenja različitih analiza te pravovremenog uočavanja određenih odstupanja te uzroka istih. Prema Etemadi i Kazeminia $(2014,513)$ upravljačke računovođe troše dodatno vrijeme za povećanu učestalost i broj različitih vrsta periodičnih internih izvještaja radi implementacije IIS.

Kao još jedan aspekt upravljačkog računovodstva, izrada i kontrola financijskog plana se mijenja pod utjecajem implementacije IIS budući da omogućuje detaljnije i preciznije predviđanje i planiranje poslovanja (Ponorica, Al-Saedi i Sadik, 2014, 686). Financijski plan postaje dinamičan i fleksibilan uz smanjenje vremena potrebnog za izradu istoga zbog upotrebe IIS (Malinić i Todorović, 2012, 737). Osim smanjenja vremena potrebnog za izradu financijskog plana zbog uporabe IIS također je za očekivati da se u značajnoj mjeri 
realizira analiza odstupanja između ostvarenih i planiranih varijabli iz financijskog plana kroz IIS.

Jedno od područja koje je privuklo izrazit interes istraživača jest utjecaj implementacije IIS na uporabu modernih tehnika upravljačkog računovodstva. Unatoč tome što su ranija istraživanja utvrdila vrlo mali utjecaj implementacije IIS na usvajanje modernih tehnika upravljačkog računovodstva (Booth, Matolcsy i Wieder, 2000, 16; Granlund i Malmi, 2002, 312; Scapens i Jayazeri, 2003, 221), za očekivati je da će implementacija IIS ipak rezultirati usvajanjem modernih tehnika upravljačkog računovodstva, kao što su $\mathrm{ABC}$ (engl. Activity-Based Costing) i TC (engl. Target Costing) (Malinić i Todorović, 2012, 735; Pervan i Dropulić, 2019, 34). Prema istraživanju Gullkvist $(2013,159)$ postoji veza između implementacije modernih tehnika upravljačkog računovodstva te uspješnosti, opsega i dobi implementiranog IIS.

Implementacija IIS odražava se i na zaposlenike u društvu te njihova radna mjesta slijedom čeka su neki autori analizirali utjecaj implementacije IIS na zaposlenike (u računovodstvu/kontrolingu/financijama) koji sudjeluju u internom izvještavanju. Prema istraživanju Etemadi i Kazeminia $(2014,513)$ uloga upravljačkih računovođa se značajno mijenja i to od prikupljanja podataka i izvještavanja o prošlim događajima prema aktivnim partnerima u planiranju i kontroli. Prema Sangester, Leech i Grabski $(2009,135)$ upravljačke računovođe moraju biti analitičniji i više gledati prema naprijed, dok bi se trebale poboljšati njihove komunikacijske i prezentacijske vještine. Također, mogućnost IIS da kombinira ili zamijeni određene zadaće upravljačkog računovodstva neizbježno vodi do promjene temeljne prirode samog posla upravljačkog računovođe (Fernandez, Zaino i Ahmad, 2018, 115). Priroda odgovornosti upravljačkih računovođa se razvija i mijenja od pukog izvještavanja o agregiranim povijesnim podacima do uključivanja mjerenja performansi organizacije i pružanja menadžmentu informacija u vezi odlučivanja (Appelbaum et al., 2017, 41).

Usvajanje i primjena IIS rezultira promjenama u upravljačkom računovodstvu, ne samo u aspektu internog izvještavanja menadžera, već i u aspektu izrade i kontrole financijskog plana, uporabe modernih tehnika upravljačkog računovodstva ali i samoga posla zaposlenika koji sudjeluju u internom izvještavanju (Pervan i Dropulić, 2019, 34).

\section{UZORAK I METODOLOGIJA ISTRAŽIVANJA}

\subsection{Opis uzorka}

Podaci za empirijsko istraživanje utjecaja IIS na praksu upravljačkog računovodstva prikupljeni su pomoću on-line upitnika distribuiranog društvima za osiguranje i reosiguranje u Bosni i Hercegovini (BIH) u periodu od svibnja do lipnja 2020. godine. U istraživanje su uključena društva prema popisu Agencije za osiguranje u Bosni i Hercegovini prema kojoj je utvrđeno da u BIH ima 26 društava za osiguranje i jedno društvo za reosiguranje (tablica 1). Poveznica za on-line upitnik zajedno s popratnim pismom je poslana na e-mail adrese menadžera društava, kao što su rukovoditelji financija, upravljačke računovođe i sl., za koje se smatra da imaju odgovarajuće znanje o implementaciji IIS te učincima istoga na praksu upravljačkog računovodstva. Nakon pet tjedana prikupljeno je šest odgovora, što predstavlja stopu povrata od 22,22\%. 
Tablica 1. Popis društava za osiguranje i reosiguranje u BIH

\begin{tabular}{|c|c|}
\hline $\mathrm{Rb}$. & Naziv društva \\
\hline 1 & Adriatic osiguranje d.d. \\
\hline 2 & ASA osiguranje d.d. \\
\hline 3 & Atos osiguranje a.d. \\
\hline 4 & Osiguranje Aura a.d. \\
\hline 5 & Brčko-gas osiguranje d.d. \\
\hline 6 & Camelija osiguranje d.d. \\
\hline 7 & Central osiguranje d.d. \\
\hline 8 & Croatia osiguranje d.d. \\
\hline 9 & Drina osiguranje a.d. \\
\hline 10 & Dunav osiguranje a.d. \\
\hline 11 & Euroherc osiguranje d.d. \\
\hline 12 & Euros osiguranje a.d. \\
\hline 13 & Osiguranje Garant d.d. \\
\hline 14 & Grawe osiguranje a.d. \\
\hline 15 & Grawe osiguranje d.d. \\
\hline 16 & Krajina osiguranje a.d. \\
\hline 17 & Mikrofin osiguranje a.d. \\
\hline 18 & Nešković osiguranje a.d. \\
\hline 19 & Premium osiguranje a.d. \\
\hline 20 & Sarajevo osiguranje d.d. \\
\hline 21 & SAS - Super P osiguranje a.d. \\
\hline 22 & Triglav osiguranje a.d. \\
\hline 23 & Triglav osiguranje d.d. \\
\hline 24 & Uniqa osiguranje d.d. \\
\hline 25 & Vienna osiguranje d.d. \\
\hline 26 & Wiener osiguranje a.d. \\
\hline 27 & Bosna reosiguranje d.d. \\
\hline
\end{tabular}

Izvor: Agencija za osiguranje u Bosni i Hercegovini, <raspoloživo na: http://www.azobih.gov.ba/drustva/default. aspx?id=28\&langTag=bs-BA />, [pristupljeno 01. 05. 2020.].

Osiguravajuća društva koja su odgovorila na upitnik zajednički drže 49,44 \% udjela na tržištu osiguranja u BIH te se zato ovaj povrat smatra prihvatljivim. 


\subsection{Opis varijabli}

Kako bi se provelo empirijsko istraživanje potrebno je definirati i opisati korištene varijable te njihovo mjerenje. Tablica 2 prikazuje karakteristike IIS koje su analizirane u ovome istraživanju.

Tablica 2. Karakteristike IIS

\begin{tabular}{|c|l|l|}
\hline $\begin{array}{c}\text { Redni } \\
\text { broj }\end{array}$ & \multicolumn{2}{|c|}{ Karakteristike IIS } \\
\hline 1 & Opseg & $\begin{array}{l}\text { Broj implementiranih osnovnih modula ERP sustava i } \\
\text { specijaliziranih aplikacija izvan osnovnih ERP modula }\end{array}$ \\
\hline 2 & $\begin{array}{l}\text { Vrijeme } \\
\text { primjene }\end{array}$ & $\begin{array}{l}\text { Prosječan broj godina korištenja modula ERP sustava i } \\
\text { specijaliziranih aplikacija izvan osnovnih ERP modula }\end{array}$ \\
\hline 3 & $\begin{array}{l}\text { Uspješnost } \\
\text { implementacije }\end{array}$ & $\begin{array}{l}\text { Prosječna ocjena uspješnost implementacije modu- } \\
\text { la ERP sustava i specijaliziranih aplikacija izvan os- } \\
\text { novnih ERP modula }\end{array}$ \\
\hline 4 & $\begin{array}{l}\text { Opseg } \\
\text { iskorištenosti }\end{array}$ & $\begin{array}{l}\text { Prosječan opseg iskorištenosti mogućnosti modu- } \\
\text { la ERP sustava i specijaliziranih aplikacija izvan os- } \\
\text { novnih ERP modula }\end{array}$ \\
\hline 5 & $\begin{array}{l}\text { Analitičke } \\
\text { mogućnosti }\end{array}$ & 9 pitanja na Likertovoj skali od 5 stupnjeva \\
\hline
\end{tabular}

Izvor: prilagođeno prema Pervan i Dropulić, 2019, 30.

Kao što je već navedeno svrha ovoga istraživanja je analiza utjecaja implementacije IIS na praksu upravljačkog računovodstva. Tablica 3 prikazuje dimenzije upravljačkog računovodstva koje su analizirane u ovome istraživanju.

Tablica 3. Dimenzije upravljačkog računovodstva

\begin{tabular}{|c|l|l|}
\hline $\begin{array}{c}\text { Redni } \\
\text { broj }\end{array}$ & \multicolumn{2}{|c|}{ Dimenzije upravljačkog računovodstva } \\
\hline 1 & Prikupljanje podataka & $\begin{array}{l}9 \text { pitanja na Likertovoj skali od } \\
5 \text { stupnjeva }\end{array}$ \\
\hline 2 & Interno izvještavanje menadžera & $\begin{array}{l}15 \text { pitanja na Likertovoj skali od } \\
5 \text { stupnjeva }\end{array}$ \\
\hline 3 & $\begin{array}{l}\text { Izrada i kontrola financijskog } \\
\text { plana }\end{array}$ & $\begin{array}{l}13 \text { pitanja na Likertovoj skali od } \\
5 \text { stupnjeva }\end{array}$ \\
\hline 4 & $\begin{array}{l}\text { Implementacija modernih } \\
\text { tehnika upravljačkog računovodstva }\end{array}$ & $\begin{array}{l}5 \text { pitanja na Likertovoj skali od } \\
5 \text { stupnjeva }\end{array}$ \\
\hline 5 & $\begin{array}{l}\text { Zaposlenici koji sudjeluju u } \\
\text { internom izvještavanju }\end{array}$ & $\begin{array}{l}7 \text { pitanja na Likertovoj skali od } \\
5 \text { stupnjeva }\end{array}$ \\
\hline
\end{tabular}

Izvor: prikaz autora. 
Osim navedenog, istraživanjem se želio utvrditi i utjecaj implementacije IIS na sposobnost društva da adekvatno odgovori na aktualnu COVID-19 krizu promatrano kroz tri aspekta doprinosa implementiranog IIS:

1) Efikasnijem odgovoru na COVID-19 krizu u smislu prilagodbe na novonastalu situaciju

2) Smanjenju gubitaka uslijed COVID-19 krize

3) Reorganiziranju načina rada uslijed COVID-19 krize.

\section{REZULTATI ISTRAŽIVANJA}

Prema dobivenim rezultatima može se zaključiti da je osnovni modul, Financijsko računovodstvo, najzastupljeniji među anketiranim društvima odnosno svih 6 društava koristi navedeni modul u svome poslovanju. Također, što se tiče specijaliziranih aplikacija izvan osnovnih ERP modula, Izrada menadžerskih izvještaja, se koristi u svih 6 anketiranih društava. U tablici 4 su prikazani podaci o implementiranim osnovnim modulima ERP sustava i specijaliziranih aplikacija izvan osnovnih ERP modula odnosno, karakteristike implementiranog IIS.

Tablica 4. Karakteristike implementiranog IIS u djelatnosti osiguranja

\begin{tabular}{|l|c|c|c|c|}
\hline Osnovni ERP moduli & $\begin{array}{c}\text { Broj } \\
\text { društava }\end{array}$ & $\begin{array}{c}\text { Vrijeme } \\
\text { primjene }\end{array}$ & $\begin{array}{c}\text { Uspješnost } \\
\text { implementacije }\end{array}$ & $\begin{array}{c}\text { Opseg } \\
\text { iskorištenosti }\end{array}$ \\
\hline Financijsko računovodstvo & 6 & 10 & 4 & 85 \\
\hline $\begin{array}{l}\text { Upravljanje dokumentaci- } \\
\text { jom }\end{array}$ & 4 & 8 & 5 & 88 \\
\hline $\begin{array}{l}\text { Analiza poslovanja/poslov- } \\
\text { na analitika/ kontroling }\end{array}$ & 4 & 10 & 4 & 78 \\
\hline Prodaja i marketing & 3 & 5 & 4 & 83 \\
\hline Nabava i skladištenje & 1 & 10 & 5 & 90 \\
\hline Ljudski resursi & 4 & 9 & 5 & 95 \\
\hline Elektroničko poslovanje & 3 & 9 & 5 & 95 \\
\hline Kontrola kvalitete & 2 & 6 & 4 & 50 \\
\hline $\begin{array}{l}\text { Specijalizirane aplikacije } \\
\text { izvan osnovnih ERP modula }\end{array}$ & $\begin{array}{c}\text { Broj } \\
\text { društava }\end{array}$ & $\begin{array}{c}\text { Vrijeme } \\
\text { primjene }\end{array}$ & $\begin{array}{c}\text { Uspješnost } \\
\text { implementacije }\end{array}$ & $\begin{array}{c}\text { Opseg } \\
\text { iskorištenosti }\end{array}$ \\
\hline Konsolidacija izvještaja grupe & 3 & 11 & 5 & 100 \\
\hline Izrada financijskih planova & 4 & 10 & 4 & 70 \\
\hline $\begin{array}{l}\text { Izrada menadžerskih } \\
\text { izvještaja }\end{array}$ & 6 & 12 & 4 & 78 \\
\hline Analiza poslovnih procesa & 2 & 8 & 5 & 100 \\
\hline $\begin{array}{l}\text { Alokacija troškova na } \\
\text { aktivnosti }\end{array}$ & 4 & 10 & 4 & 87 \\
\hline
\end{tabular}

Izvor: prikaz autora na temelju istraživanja. 
Prosječan broj godina korištenja IIS u djelatnosti osiguranja iznosi 9 godina, što potvrđuje činjenicu zastupljenosti IIS u djelatnosti osiguranja duži niz godina. Prosječna ocjena uspješnosti implementacije IIS je 4 (ocjena 4 predstavlja uspješnu implementaciju) dok prosječan opseg iskorištenosti mogućnosti modula iznosi visokih $85 \%$. U $50 \%$ anketiranih društava implementirani IIS nakon inicijalne implementacije značajno je dodatno prilagođavan prema potrebama društva, dok je u $100 \%$ anketiranih društava tijekom ili nakon implementacije IIS bila organizirana posebna obuka zaposlenika za korištenje IIS čija je procijenjena kvaliteta ocjenjena kao vrlo dobra u tri društva (50 \%). Također, implementirani IIS u značajnoj mjeri podržava praćenje poslovanja kroz ključne financijske i nefinancijske pokazatelje kako na razni društva, tako i na razini dijelova društva. Osim toga, značajno podržava rudarenje podataka, analizu poslovnih procesa i alokaciju troškova na aktivnosti te izradu prognoza temeljem podataka iz IIS.

Što se tiče utjecaja implementacije IIS na sposobnost društva da adekvatno odgovori na aktualnu COVID-19 krizu, utvrđen je značajan doprinos (prosječna ocjena 3,72 $\approx 4$ ) implementiranog IIS efikasnijem odgovoru na COVID-19 krizu u smislu prilagodbe na novonastalu situaciju, smanjenju gubitaka uslijed COVID-19 krize te reorganiziranju načina rada uslijed COVID-19 krize (tablica 5).

Tablica 5. Utjecaj implementacije IIS na sposobnost društva da adekvatno odgovori na aktualnu COVID-19 krizu

\begin{tabular}{|l|c|c|}
\hline U kojoj mjeri je implementirani IIS doprinio & M & SD \\
\hline $\begin{array}{l}\text {.. efikasnom odgovoru na COVID-19 krizu u smislu prilagodbe } \\
\text { na novonastalu situaciju }\end{array}$ & 3,67 & 1,03 \\
\hline$\ldots$ smanjenju gubitaka uslijed COVID-19 krize & 3,67 & 1,03 \\
\hline .. reorganiziranju načina rada uslijed COVID-19 krize & 3,83 & 1,17 \\
\hline M - aritmetička sredina; SD - standardna devijacija & \\
\hline
\end{tabular}

Izvor: prikaz autora na temelju istraživanja.

Prema rezultatima istraživanja utvrđen je djelomičan utjecaj implementacije IIS na upravljačko računovodstvo u vidu prikupljanja podataka koji se koriste u svrhu internog izvještavanja menadžera (prosječna ocjena $3,48 \approx 3$ ), s tim da se u vrlo značajnoj mjeri računovodstveni podaci iz društva pohranjuju u bazi podataka koja je integralni dio IIS. Također, u značajnoj mjeri je povećana ažurnost i točnost podataka koji se prikupljaju iz društva i okruženja zbog implementacije IIS. Na sljedećem grafikonu (grafikon 1) prikazani su rezultati utjecaja implementacije IIS na prikupljanje podataka koji se koriste u svrhu internog izvještavanja menadžera.

Kao što se može vidjeli na grafikonu 1 kod tri društva $(50,00 \%)$ je evidentiran značajan, a kod jednog društva (16,67 \%) vrlo značajan utjecaj implementacije IIS na prikupljanje podataka koji se koriste u svrhu internog izvještavanja menadžera. Kod ostala dva društva $(33,33 \%)$ je evidentiran utjecaj implementacije IIS manjim dijelom na prvu dimenziju upravljačkog računovodstva odnosno na prikupljanje podataka.

Što se tiče utjecaja implementacije IIS na upravljačko računovodstvo u vidu internog izvještavanja menadžera (grafikon 2 ) ostvarena je prosječna ocjena 3,64 $\approx 4$ koja pred- 
Grafikon 1. Utjecaj implementacije IIS na upravljačko računovodstvo - 1) prikupljanje podataka

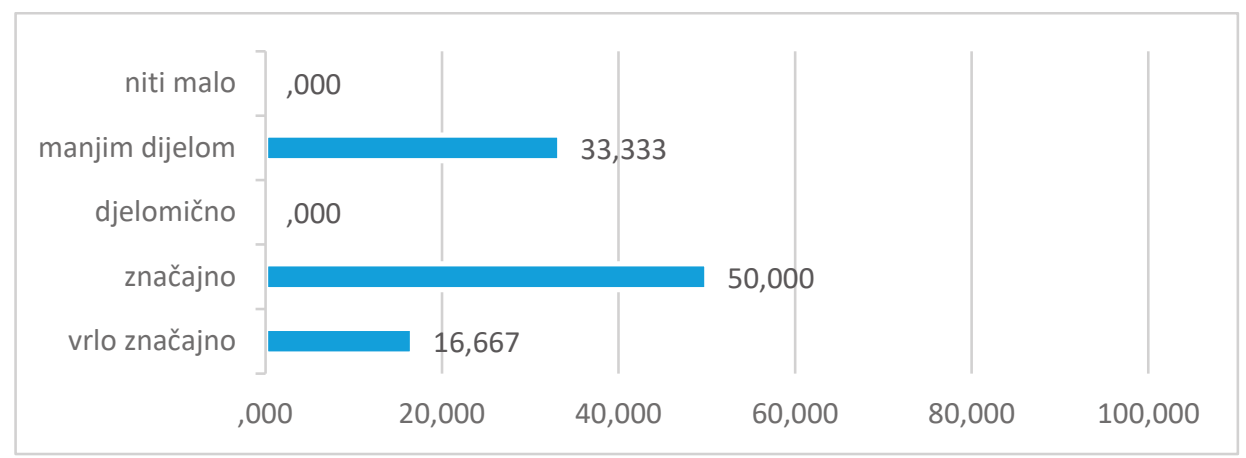

Izvor: prikaz autora na temelju istraživanja.

stavlja značajan utjecaj. Stavke kod kojih je utvrđen samo djelomičan utjecaj vezane su za kreiranje, kroz IIS, izvanrednih izvještaja te izvještaja o ostvarenim odnosima s poslovnim partnerima i zaposlenicima. Također, relevantno je istaknuti da je u značajnoj mjeri skraćeno vrijeme potrebno za interno izvještavanje dok se je značajno povećala učestalost i broj različitih vrsta periodičnih izvještaja.

Grafikon 2. Utjecaj implementacije IIS na upravljačko računovodstvo - 2) interno izvještavanje menadžera

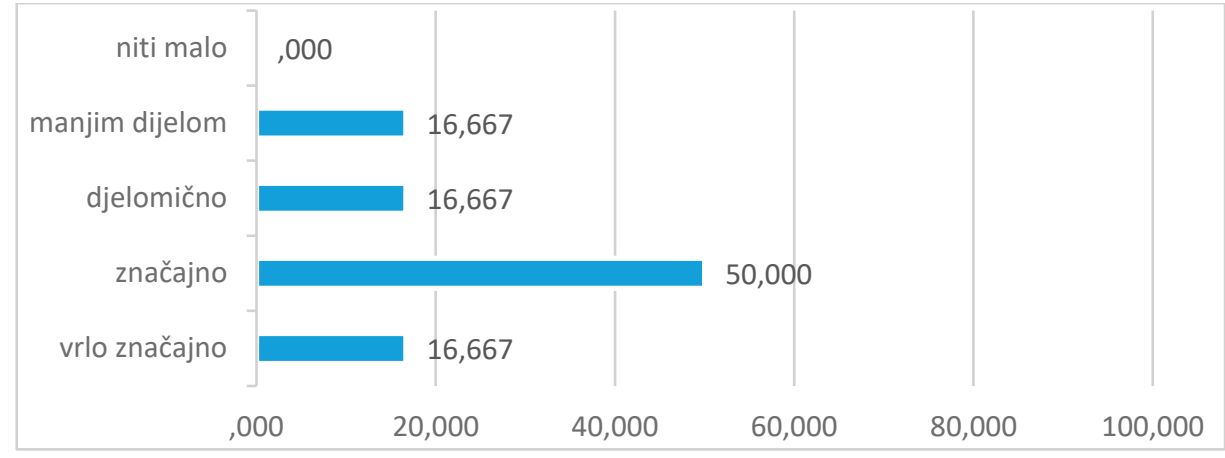

Izvor: prikaz autora na temelju istraživanja.

Na grafikonu 2 se može vidjeti da je kod tri društva $(50,00 \%)$ evidentiran značajan utjecaj implementacije IIS na interno izvještavanje menadžera. Po jedno društvo $(16,67 \%)$ je evidentiralo utjecaj implementacije IIS na drugu dimenziju upravljačkog računovodstva, interno izvještavanje menadžera, manjim dijelom, djelomično i vrlo značajno.

Djelomičan utjecaj implementacije IIS na upravljačko računovodstvo ostvaren je kod izrade i kontrole financijskog plana (grafikon 3) s obzirom da je ostvarena prosječna ocjena $3,15 \approx 3$. Međutim, u značajnoj mjeri se financijski plan izrađuje u okviru IIS te je u značajnoj mjeri smanjeno vrijeme potrebno za izradu financijskog plana zbog uporabe IIS.

Kao što se može vidjeli na grafikonu 3 kod tri društva $(50,00 \%)$ je evidentiran značajan, a kod jednog društva (16,67 \%) vrlo značajan utjecaj implementacije IIS na izradu i kontrolu financijskog plana. Kod ostala dva društva $(33,33 \%)$ nije evidentiran utjecaj imple- 
Grafikon 3. Utjecaj implementacije IIS na upravljačko računovodstvo - 3) izradu i kontrolu financijskog plana

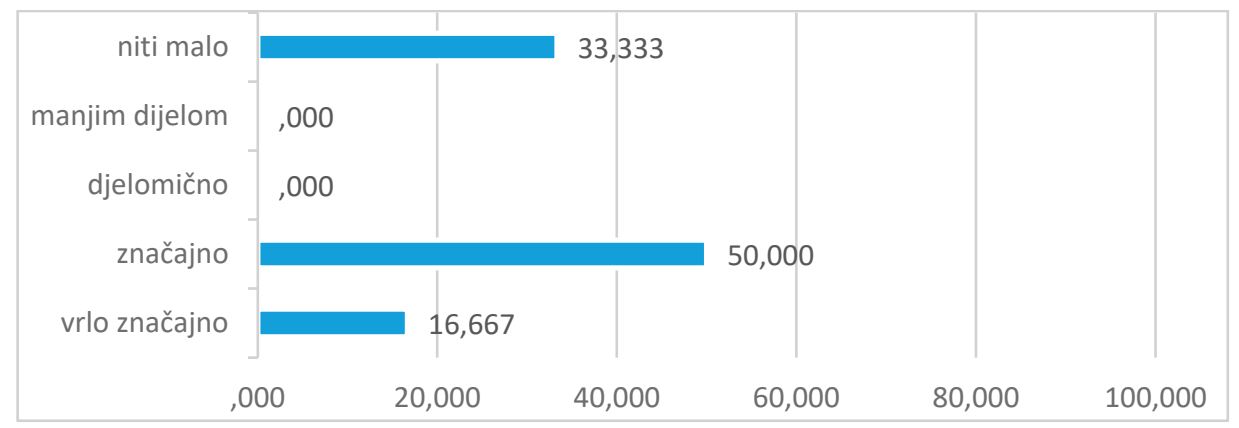

Izvor: prikaz autora na temelju istraživanja.

mentacije IIS na treću dimenziju upravljačkog računovodstva odnosno na izradu i kontrolu financijskog plana.

Još jedan značajan utjecaj implementacije IIS na upravljačko računovodstvo ostvaren je kod implementacije modernih tehnika upravljačkog računovodstva (prosječna ocjena $3,63 \approx 4)$. Može se zaključiti da je u značajnoj mjeri uporaba IIS rezultirala uporabom ABC (Activity-Based Costing), BSC (Balanced Scorecard), TC (Target Costing), Benchmarking i KPI (Key Performance Indicators). Kod tri društva (50,00 \%) evidentiran značajan utjecaj implementacije IIS na implementaciju modernih tehnika upravljačkog računovodstva. Po jedno društvo (16,67 \%) je evidentiralo utjecaj implementacije IIS na četvrtu dimenziju upravljačkog računovodstva, implementaciju modernih tehnika upravljačkog računovodstva, manjim djelom, djelomično i vrlo značajno (grafikon 4).

Grafikon 4. Utjecaj implementacije IIS na upravljačko računovodstvo - 4) implementaciju modernih tehnika upravljačkog računovodstva

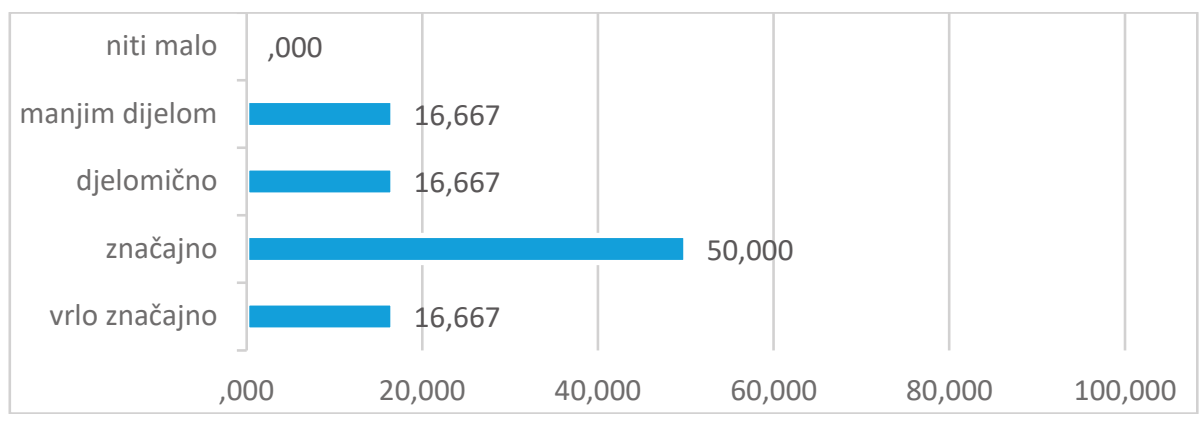

Izvor: prikaz autora na temelju istraživanja.

Što se tiče utjecaja implementacije IIS na zaposlenike (u računovodstvu/kontrolingu/ financijama) koji sudjeluju u internom izvještavanju ostvarena je prosječna ocjena $3,17 \approx 3$ koja predstavlja djelomičan utjecaj. Međutim, u značajnoj mjeri je skraćen utrošak radnog vremena potrebnog za prikupljanje podataka za interno izvještavanje zbog implementacije IIS te je u značajnoj mjeri bilo potrebno unaprijedi znanje zaposlenika o poslovnim procesima zbog implementacije IIS. 
Grafikon 5. Utjecaj implementacije IIS na upravljačko računovodstvo - 5) zaposlenike koji sudjeluju u internom izvještavanju

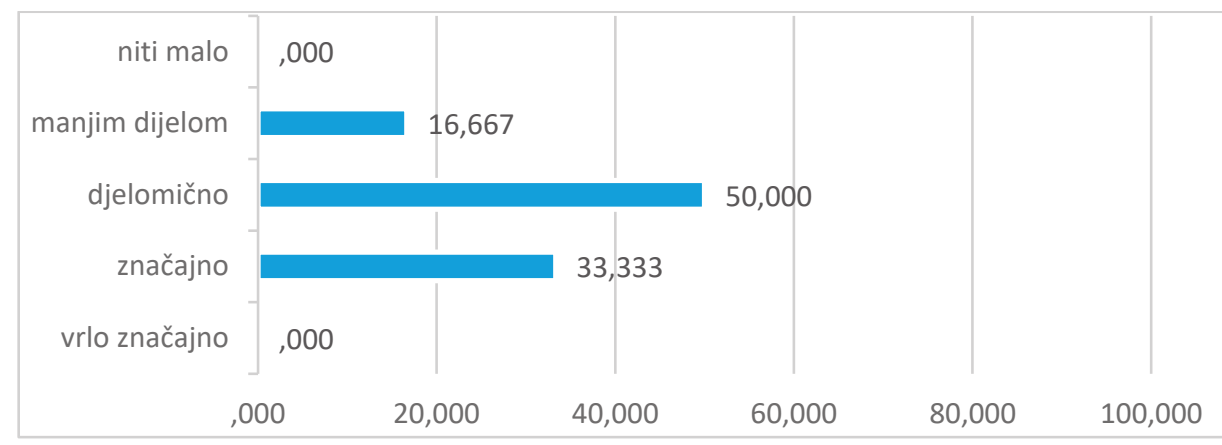

Izvor: prikaz autora na temelju istraživanja.

Kao što se može vidjeli na grafikonu 5 kod tri društva $(50,00 \%)$ je evidentiran djelomičan, a kod dva društva (33,33 \%) značajan utjecaj implementacije IIS na zaposlenike koji sudjeluju u internom izvještavanju. Kod jednog društva $(16,67 \%)$ je evidentiran utjecaj implementacije IIS manjim dijelom na petu dimenziju upravljačkog računovodstva odnosno na zaposlenike koji sudjeluju u internom izvještavanju.

Tablica 6. Sumarni prikaz utjecaja implementacije IIS na praksu upravljačkog računovodstva u djelatnosti osiguranja BIH

\begin{tabular}{|c|c|c|}
\hline Utjecaj implementacije IIS & M & SD \\
\hline $\begin{array}{l}\text {... na prikupljanje podataka koji se koriste u svrhu internog } \\
\text { izvještavanja menadžera }\end{array}$ & 3,48 & 1,38 \\
\hline ... na interno izvještavanje menadžera & 3,64 & 1,12 \\
\hline ... na izradu i kontrolu financijskog plana & 3,15 & 1,46 \\
\hline ... na implementaciju modernih tehnika upravljačkog računovodstva & 3,63 & 1,07 \\
\hline \multirow[t]{2}{*}{... na zaposlenike koji sudjeluju u internom izvještavanju } & 3,17 & 1,06 \\
\hline & 3,41 & 1,27 \\
\hline
\end{tabular}

Izvor: prikaz autora na temelju istraživanja.

U tablici 6 dan je sumarni prikaz istraživanja utjecaja implementacije IIS na praksu upravljačkog računovodstva, promatranog kroz pet dimenzija, u djelatnosti osiguranja BIH. Prema dobivenim rezultatima može se zaključiti kako implementirani IIS ostvaruje određeni djelomičan utjecaj na praksu upravljačkog računovodstva s tim da taj utjecaj nije isti kod svih promatranih dimenzija. Značajan utjecaj IIS je utvrđen na interno izvještavanje menadžera te na implementaciju modernih tehnika upravljačkog računovodstva, dok je djelomičan utjecaj utvrđen na prikupljanje podataka koji se koriste u svrhu internog izvještavanja menadžera, na zaposlenike koji sudjeluju u internom izvještavanju te na izradu i kontrolu financijskog plana. 


\section{ZAKLJUČAK}

Može se zaključiti, temeljem prethodno iznesenih podataka, kako IIS djelomično utječe na prikupljanje podataka koji se koriste u svrhu internog izvještavanja menadžera s tim da se u vrlo značajnoj mjeri računovodstveni podaci iz društva pohranjuju u bazi podataka koja je integralni dio IIS. Što se tiče utjecaja IIS na izradu i kontrolu financijskog plana on je također djelomičan, međutim u značajnoj je mjeri smanjeno vrijeme potrebno za izradu financijskog plana koji se većim dijelom izrađuje u okviru IIS. Također, utjecaj IIS na zaposlenike koji sudjeluju u internom izvještavanju je djelomičan, ali je došlo do značajnog smanjenja utroška radnog vremena potrebnog za prikupljanje podataka za interno izvještavanje kao posljedica implementacije IIS uz potrebno znatno unapređenje znanja tih istih zaposlenika. Značajan utjecaj IIS je utvrđen na interno izvještavanje menadžera odnosno, u značajnoj mjeri se povećala učestalost i broj različitih vrsta periodičnih izvještaja te na implementaciju modernih tehnika upravljačkog računovodstva.

Ograničenje istraživanja predstavlja broj društava koja su odgovorila na upitnik (6 od 26) kao i ukupni broj društava u djelatnosti osiguranja s djelovanjem u Bosni i Hercegovini. Međutim, radi se o relativno malom tržištu na kojem vodeću ulogu ima upravo 6 društava koja jesu odgovorila na upitnik budući da ista drže gotovo polovinu tržišnog udjela. Uzevši tu činjenicu u obzir, izneseni zaključci se mogu smatrati vjerodostojnom slikom stvarnog stanja na tržištu osiguranja u Bosni i Hercegovini kada je u pitanju implementacija IIS. Ta stvarna slika prije svega govori o nedovoljno razvijenoj svijesti te uporabi, prednosti i mogućnosti koje nudi kvalitetan IIS.

Doprinos ovoga istraživanja se ogleda u pružanju preciznijeg i detaljnijeg uvida u utjecaj implementacije IIS na praksu upravljačkog računovodstva u djelatnosti osiguranja Bosne i Hercegovine te pruža temelj za daljnja istraživanja u ovom području. Kako bi se omogućili temelji za bolje razumijevanje navedenog odnosa, kako u znanstvenom području, tako i u praksi, buduća istraživanja ovoga područja trebala bi proučavati IIS u širem kontekstu budući da IIS nisu izolirane, a njihovi učinci ili primjena su često popraćeni drugim utjecajnim faktorima koji mogu odrediti koliku vrijednost će generirati implementirani IIS s obzirom na velika ulaganja, kompleksnost tehnologije te poteškoće i dugotrajnost procesa implementacije. Također, budući da postoji vremenski jaz između implementacije IIS i njegovih učinaka na poslovanje društva, potrebno je u istraživanju koristiti podatke koji pokrivaju duže vremensko razdoblje kako bi se dobili reprezentativniji zaključci i bolji uvid u mnogobrojne efekte IIS.

\section{LITERATURA:}

1. Agencija za osiguranje u Bosni i Hercegovini, http://www.azobih.gov.ba/drustva/ default.aspx?id=28\&langTag=bs-BA, (accessed 1 May 2020).

2. Appelbaum, D., Kogan, A., Vasarhelyi, M., Yan, Z. (2017), Impact of business analytics and enterprise systems on managerial accounting, International Journal of Accounting Information Systems, 25, str. 29-44.

3. Booth, P., Matolcsy, Z., Wieder, B. (2000), The impacts of enterprise resource planning systems on accounting practice - the Australian experience, Australian Accounting Review, 16(1), str. 4-18. 
4. Colmenares, L. (2009), Benefits of ERP systems for accounting and financial management, Proceedings of the Academy of Information and Management Sciences, Volume 13, Number 1, New Orleans.

5. Dropulić, I. (2019), Utjecaj informacijskoh tehnologija na upravljačko računovodstvo, Zbornik radova Ekonomskog fakulteta Sveučilišta u Mostaru (Journal of Economy and Business), No. Posebno izdanje 2019, str. 62-76.

6. Dwi May Adi Indra, L., Noorlailie, S., Isnalita, I. (2018), Impact of enterprise resource planning systems on the accounting information relevance and firm performance, Russian Journal of Agricultural and Socio-Economic Sciences (RJOAS), 8(80), str. 81-87.

7. Etemadi, H., Kazeminia, S. (2014), Impact of Enterprise Resource Planning Systems (ERP) on Management Accountants, Management and Administrative Sciences Review, 3(4), str. 507-515.

8. Fernandez, D., Zaino, Z., Ahmad, H. (2018), An Investigation of Challenges in Enterprise Resource Planning (ERP) Implementation: The Case of Public Sector in Malaysia, International Journal of Supply Chain Management, 7(3), str. 113-117.

9. Granlund, M., Malmi, T. (2002), Moderate impact of ERPS on management accounting: a lag or permanent outcome? Management Accounting Research, 13(3), str. 299321.

10. Gullkvist, B. M. (2013), Drivers of change in management accounting practices in an ERP environment, International Journal of Economic Sciences and Applied Research, 6(2), str. 149-174.

11. Kanellou, A., Spathis, C. (2011, July 11-12) Accounting Benefits and Satisfaction in an ERP Environment, Paper presented 8th International Conference on Enterprise Systems, Accounting and Logistics: 8th ICESAL 2011, Thassos Island, Greece.

12. Malinić, S., Todorović, M. (2012), How Does Management Accounting Change under the Influence of ERP? Economic Research - Ekonomska Istraživanja, 25(3), str. 722751.

13. Milanović Glavan, LJ. (2014), Procesna informacijska tehnologija u poduzećima Republike Hrvatske, Zbornik radova Veleučilišta u Šibeniku, 3-4, str. 35-48.

14. Pervan, I., Dropulić, I. (2019), The Impact of Integrated Information Systems on Management Accounting: Case of Croatia, Management: Journal of Contemporary Management Issues, 24(1), str. 21-38.

15. Ponorica, A. G., Al-Saedi, A. H. J., Sadik, H. H. (2014), The impact of enterprise resource planning systems on management accounting, Challenges of the Knowledge Society, 4(1), str. 682-690.

16. Sangster, A., Leech, S. A., Grabski, S. (2009), ERP implementations and their impact upon management accountants, Journal of Information Systems and Technology Management, 6(2), str. 125-142.

17. Scapens, R., Jazayeri, M. (2003), ERP systems and Management Accounting Change: Opportunities or Impacts? A Research Note. European Accounting Review, 12(1), str. 201-233. 